\section{The Impact of Socio-Economical Status on the Quality of Life of Children with Asthma}

\section{Paraschiva Cherecheș-Panța*, Claudia Felicia Pop*, Petronela Coblișan and Sorin Claudiu Man}

University of Medicine and Pharmacy, Iuliu Hațieganu, Cluj-Napoca, Romania

\begin{abstract}
Low socioeconomic level may contribute to the severity of asthma, frequency of exacerbation, and hospitalization and affects the quality of life. The aim of the study was to evaluate the impact of socioeconomic status (SES) on general score of quality of life (GSQL).

Methods: The study group included children aged between 8-16 years with persistent asthma, and we followed them up 12 months. We analyzed the location and the size of the household, educational level, and employment status of parents and family income. The GSQL was obtained based on the questionnaire of quality of life in children with asthma. According to the SES, we divided the study group into high income and low-income groups.
\end{abstract}

Results: Half of the patients belonged to families with low income There were no significant differences in GSQL regarding the living area, educational level, and parents' employment status. The general score of quality of life was higher in patients from the high-income group than those with lower income at the beginning of the study $(5.04 \pm 1.09$ versus $4.43 \pm 0.97 ; p=0.0101)$. Alter 12 months $G S Q L$ increased significantly in both groups $(6.57 \pm 0.57$ versus $6.49 \pm 0.56$; $p=0.3167$ ). The quality of life was not affected by atopic status.

Conclusions: The low income has a negative impact on children GSQL. The educational level and employment status of parents, rural area, and the association of other allergic diseases do not affect the quality of life.

Keywords: Allergic rhinitis; Asthma; Quality of life; Socio-economical status

*Corresponding author: Paraschiva Cherecheș-Panța, Claudia Felicia Pop University of Medicine and Pharmacy, Iuliu Hatieganu, Cluj-Napoca, Romania, Tel: 03339981912; Email: pusacherechespanta@gmail.com; cindolean@gmail. com

Citation: Cherecheș-Panța P, Pop CF, Coblișan P, Man SC (2020) The Impact of Socio-Economical Status on the Quality of Life of Children with Asthma. J Emerg Med Trauma Surg Care 7: 054.

Received: October 08, 2020; Accepted: October 22, 2020; Published: October 29, 2020

Copyright: (c) 2020 Cherecheș-Panța P, et al. This is an open-access article distributed under the terms of the Creative Commons Attribution License, which permits unrestricted use, distribution, and reproduction in any medium, provided the original author and source are credited.

\author{
Abbreviations \\ GINA: Global Initiative for Asthma \\ GSQL: General Score of Quality of Life \\ $\mathrm{p}=$ The Index of the Statistic Probability \\ PAQLQ: Paediatric Asthma Quality of Life Questionnaire \\ SES: Socioeconomic Status
}

\section{Introduction}

Asthma is a multifactorial and heterogeneously disorder, the most frequent chronic disease in children. In developed countries, the incidence of the disease has an increasing trend in children. During the past two decades in Romania, asthma prevalence in children increased from $3.4 \%$ to $5-7 \%$ [1-4]. Due to the chronic course, asthma affects children from the physical point of view and psychological and social aspects. The chronic course implies a particular situation in an individual's life. The disease generates psychic stress through the problem created by the clinical features. The consequences of recurrent exacerbations and daily medication that is required may induce behavior changes or inferiority complex. There are different modalities in which the child reacts to chronic disease. They might present dependency, self-accusation, anxiety, depression, fear, regression, hostility, self-interest, or self-isolation [5]. When the parents find out that their child has a disorder with chronic evolution, a real shock may occur. The parents' attitude will be either hyperprotection of the child, isolation of the child, or embarrassment in the community. Often, they deprive the child of positive experiences. The child's siblings' reaction may be feelings of frustration and dissatisfaction, feelings of shame as a report to their school-mates and playmates, or "maternal" feelings. These health caregivers' concerns evolved towards the concept's appearance for evaluating a chronic disease called quality of life. This is a modern criterion of appreciation of the disease's impact on the patient's life that became a part of the monitoring plan during the past decade.

Quality of life represents "the impact of the disease and consequences of the therapy on the patient's activity and well-being as they are perceived by the patient himself" [6,7]. The subjective methods of evaluation represented by questionnaires are used on a large scale. For children, the development of specific evaluation instruments represented a real challenge because the children must be able to undertake the test by themselves, without their parents' help. The questionnaire implies a certain level of understanding and knowledge concerning the disease and the capacity of reading. The most frequently used questionnaire on the quality of life of the asthmatic child is "Paediatric Asthma Quality of Life Questionnaire" (PAQLQ) published by Juniper E. [7-9]. It contains 28 items (questions) from 3 domains: 10 items for symptoms, five items for activities, and eight items for emotions.

Published data concerning the relationship between socioeconomical factors and asthma reveal a higher prevalence of asthma in subjects that belong to families with lower income [10]. Also, 
studies showed that asthma is more severe in people with lower income [11-12]. The majority of these reports include adults with asthma or chronic obstructive pulmonary disease.

The authors assessed the impact of socio-economical status (SES) on children's quality of life with asthma. They analysed the relationship between atopy and asthma-related to the socioeconomic level.

\section{Materials and Methods}

\section{Study design}

We underwent a cohort, prospective, opened, an interventional study in which we evaluated the described parameters during 12 months of follow-up, with a total of three visits, at the beginning of the study, after three months, and after 12 months.

\section{Population}

Our study group consisted of children with the following inclusion criteria:

1. Diagnosis of asthma at least six months before inclusion in concordance with current guidelines [13];

2. The age of the patients between 8 and 16 years old;

3. The consent of the child to fill in the questionnaire;

4. The agreement of parents to participate to the study and to offer specific data regarding their SES. We excluded from the study group patients associated with other diseases except for allergic rhinitis and/ or eczema or atopic dermatitis.

The exclusion criteria were:

1. Symptoms consistent with asthma (recurrent wheezing, persistent cough, e.g.) without a confirmed diagnosis of asthma;

2. Patients younger than eight years or older than 16 years old;

3. Association of other chronic diseases, except for allergic rhinitis, atopic dermatitis or eczema, that may influence the quality of life (gastroesophageal reflux, heart abnormalities, e.g.);

4. Lack of compliance.

All patients underwent spirometry at the time of each visit. The atopic status was assessed by allergic skin prick tests that performed at the first visit. We used the Halcis case from S.C.Diagnosis and Therapy Halcis Allergy Romania. We tested both indoor allergens: house dust mites (Dermatophgoides pteronyssinus and Dermatophgoides farinae), molds (Cladosporium herbarum, Aspergillus fumigatus, Alternaria alternata), and outdoor allergens: grass or trees pollens (e.g., Ragweed, Artemisia vulgaris, Parietaria judaica) and pets (cat and $\mathrm{dog}$ ). We measured the skin reaction, reported the wheal's size, and interpreted it as a positive reaction if the diameter was $>3 \mathrm{~mm}$. The same investigator on each patient performed the skin prick tests.

The study group was divided into two subgroups according to the average income in the family. By the time of the study, during the early 2000s, the minimum gross income in the Romanian economy presented by the state agencies varied according to the exchange rate and according to the economic performance between 22 and 37 Euros. We used a 26 Euro cut-off split between group A, with a low income, below 26 Euro and group B, with an income higher than 26 Euro.
During the selection phase, we used the following parameters to assess the socioeconomic status: rural or urban location of child's home, crowding of the house, the monthly income per family member as described above, the educational level, and the profession of both parents.

\section{Method}

The quality of life was assessed using the questionnaire "Pediatric Asthma Quality of Life Questionnaire" (PAQLO). The questionnaire was translated into Romanian and adapted than validated [14]. For each of the 23 items, there is a scale between 1 and 7 . A lower score of 1 means a lower quality of life, and 7 represents a good perception of life. The general score is calculated during the three visits based on the three domains: symptoms, activities, and emotions (the arithmetic mean of each domain). A difference of a minimum of 0.5 in the general score of quality of life (GSQL) or the scores for each domain means a significant change in life quality from a visit to the next [8].

\section{Ethics}

According to the local hospital policy, all parents/legal guardians consented to participation in the study by providing informed written consent. The study protocol was approved by both the ethical committee of "Iuliu Hatieganu" University of Medicine and Pharmacy and Children's Emergency Hospital Cluj-Napoca.

\section{Statistical analysis}

We used SPC for Excel Software for data analysis. The chi-square test and Fisher test was used to compare proportions, and results are presented as percentages with $p$ values and, when appropriate. We considered a significant change when $\mathrm{p}$ values were $<0.05$. Nominal data were reported as the frequency, percentage $(n, \%)$, and median.

\section{Results}

Seventy-four children with persistent asthma fulfilled the inclusion criteria for the study group. After three months, 10 of them were excluded, so that 64 patients were evaluated for 12 months of the study. The exclusion was due to either withdrawal of the consent (2 cases) or poor compliance (8 cases).

The patients' mean age was $11.0 \pm 2.60$ years (range 8 to 16 years old), the majority being males (36 patients, 66.6\%). Demographic characteristics are summarized in table 1.

Concerning the site of their homes, $72 \%$ of the subjects (46 out of 64 patients) lived in cities. The proportion of patients from rural areas is significantly higher in the low-income group than in the highincome group (14 cases, versus 4 cases). Positive skin prick tests occurred in 42 cases $(65.6 \%)$, more frequent in patients with higher income (21 patients, $70 \%$ ) than in patients from group B (21 patients, $61.7 \%)$. Analyzing the hypersensitivity, we noticed that most patients presented positive reactions for indoor allergens $(59.5 \%)$. The positive reaction of skin tests was more frequent in patients living in cities than in rural areas. Only ten from 18 patients living in countryside areas presented a positive reaction when tested by skin prick tests.

We analyzed the living site as an independent factor for the quality of life. In children that lived in a rural area, GSQL was $4.77 \pm 0.98$ at the beginning of the assessment and increased to $6.43 \pm 0.52$ after 12 months, while in patients living in cities, the initial GSQL was Volume $7 \cdot$ Issue $2 \cdot 100054$ 
$4.69 \pm 1.11$ and increased up to $6.58 \pm 0.58$. No significant differences were noticed concerning the living area, regardless of the two groups' income levels.

\begin{tabular}{|c|c|c|c|}
\hline & $\begin{array}{c}\text { Group A } \\
\text { low income }\end{array}$ & $\begin{array}{c}\text { Group B } \\
\text { high income }\end{array}$ & $\mathbf{p}$ \\
\hline No. cases & 34 cases & 30 cases & \\
\hline $\begin{array}{l}\text { Gender } \\
\text { - males } \\
\text { - females }\end{array}$ & $\begin{array}{l}21 \text { cases }(61.8 \%) \\
13 \text { cases }(38.2 \%)\end{array}$ & $\begin{array}{l}19 \text { cases }(63.3 \%) \\
11 \text { cases }(36.7 \%)\end{array}$ & $\mathrm{p}>0.05$ \\
\hline $\begin{array}{l}\text { Age of patients } \\
\text { Mean } \pm \text { SD } \\
\text { Median }\end{array}$ & $\begin{array}{c}8-16 \text { years } \\
10.97 \pm 2.04 \\
10.5 \text { years }\end{array}$ & $\begin{array}{c}8-15 \text { years } \\
11.03 \pm 1.97 \\
11.0 \text { years }\end{array}$ & $\mathrm{p}>0.05$ \\
\hline $\begin{array}{l}\text { Living area } \\
\text { - Cities } \\
\text { - Rural area }\end{array}$ & $\begin{array}{l}20 \text { cases }(58.8 \%) \\
14 \text { cases }(41.2 \%)\end{array}$ & $\begin{array}{c}26 \text { cases }(86.7 \%) \\
4 \text { cases }(13.3 \%)\end{array}$ & 0.0051 \\
\hline $\begin{array}{l}\text { Association with other allergic } \\
\text { diseases, no cases } \\
\text { - isolated asthma } \\
\text { - associated with AR and/or AD }\end{array}$ & $\begin{array}{l}12 \text { cases }(35 \%) \\
22 \text { cases }(65 \%)\end{array}$ & $\begin{array}{c}3 \text { cases }(10 \%) \\
27 \text { cases }(90 \%)\end{array}$ & $0.0002 * * *$ \\
\hline $\begin{array}{l}\text { Positive skin prick tests for one } \\
\text { or more allergens } \\
\text { - for outdoor allergens } \\
\text { - for indoor allergens } \\
\text { - for both outdoor and indoor } \\
\text { allergens }\end{array}$ & $\begin{array}{c}21 \text { cases }(61.7 \%) \\
0 \text { cases } \\
15 \text { cases } \\
6 \text { cases }\end{array}$ & $\begin{array}{c}21 \text { cases }(70.0 \%) \\
2 \text { cases } \\
10 \text { cases } \\
9 \text { cases }\end{array}$ & $\mathrm{p}>0.05$ \\
\hline
\end{tabular}

Regarding the house's crowding, 41 subjects belonged to a family where the home was not crowded (less than two persons living in a room). Most of the patients had both parents with a medium level of education, $63 \%$ of mothers, and $62 \%$ of fathers.

The relation between the general score of quality of life and the income level is presented in table 2. At the beginning of the study, there was a significant statistical difference $(\mathrm{p}=0.0101)$ between group A and group B concerning the GSQL. After 12 months, the GSQL for both groups increased significantly $(\mathrm{p}=0.0001$ and $\mathrm{p}=0.0009)$. There were no significant differences between group A and group B regarding the evolution of GSQL ( $\mathrm{p}=0.3167)$.

\begin{tabular}{|c|c|c|c|}
\hline & $\begin{array}{c}\text { Group A } \\
\text { low income } \\
(\mathbf{n}=\mathbf{3 4} \text { cases) }\end{array}$ & $\begin{array}{c}\text { Group B } \\
\text { high income } \\
\text { (n=30 cases) }\end{array}$ & $\mathbf{p}$ \\
\hline $\begin{array}{c}\text { initial GSQL } \\
\text { (MA } \pm \text { DS) } \\
\text { (Median) }\end{array}$ & $\begin{array}{c}4.43 \pm 0.97 \\
4.17\end{array}$ & $\begin{array}{c}5.04 \pm 1.09 \\
5.05\end{array}$ & 0.0101 \\
\hline $\begin{array}{c}\text { final GSQL } \\
\text { (MA DS) }\end{array}$ & $6.49 \pm 0.56$ & $6.57 \pm 0.57$ & 0.3167 \\
(Median) & 6.73 & 6.75 & \\
\hline$p$ & 0.0001 & 0.0009 & \\
\hline
\end{tabular}

Table 2: The evolution of GSQL related to the level of income per family member.

The relationship between GSQL and the parents' educational level was evaluated only for 54 patients from the initial study group. The results suggest that GSQL improved regardless of the educational level of the parents. There were significant differences between initial and after 12 months GSQL values only for cases in which parents had a medium level of education.
The evolution of GSQL related to the parent's profession was as follows: in children of mothers without a job or a low hierarchy job, the GSQL increased from was from 4.58 to $6.27(\mathrm{p}=0.0516)$. Concerning the father, there was a significant increase only in unemployed fathers $(\mathrm{p}=0.0213)$.

There are no significant differences in GSQL between patients with the positive and negative reaction of allergic skin prick tests at the beginning of the study $(\mathrm{p}=0.36)$ and the endpoint of research $(\mathrm{p}=0.31)$.

\section{Discussions}

The causes and the intensity of the low socio-economical level are different from a society to another. Various published studies suggest that the lower socio-economical level represents a restriction from medical care at high quality and adequate medication [6,15-17]. Other published studies confirm the link between asthma and a low socioeconomical level $[6,12,18,19]$. At the beginning of our research, there was a noteworthy difference concerning the GSQL $(p=0.0101)$ between the two groups of patients with a low and high-income level. After 12 months, there were no significant differences concerning the GSQL ( $\mathrm{p}=0.3167)$ between these two groups of patients with varying income levels. The increase of GSQL in patients from both income groups could be explained by applying GINA's therapy.

In our study group, most high-income group children lived in cities, whereas $42 \%$ of those in the low-income group lived in rural areas $(\mathrm{p}=0.0051)$. In adults with obstructive airway disease, this factor was correlated with a lower quality of life. Our data did not prove a significant difference in the GSQL according to the living site at the beginning of the study or the end of the follow-up period.

The GSQL evolution related to the allergic skin prick tests demonstrated no differences, during the research period, between patients with the positive and negative reaction of skin tests. Several prior studies [11,20] revealed that skin hypersensitivity is more frequent in low socio-economical persons. This research showed that skin hypersensitivity is more frequent in patients with high-income levels ( 21 from 30 patients, $70 \%$ ) than in patients with low-income levels (21 from 34 patients, $61 \%$ ).

The educational level of parents and employment status was a factor that showed no differences between the two groups in our study group. Chellammal HSJ, et al. recently published a paper in which they found that a higher educational level in adults with asthma is an important factor that correlates with a higher quality of life [21].

There is some limitation of our study that may interfere with our conclusions. We omitted in this study the analysis of the impact of comorbidities, mainly allergic rhinitis. Another bias could be the therapeutic approach, neither the long-term medication nor the adherence to therapy and the educational measures being evaluated. These data were previously published in independent reports [22-24]. Allergic rhinitis was recognized by several other authors [25-28] as risk factors for a lower quality of life.

Regarding the treatment, the therapy step is relevant and adherence to the therapeutic plan $[29,30]$. The patients in both study groups that we analysed had a daily journal for the entire study period. They recorded both clinical data and medication daily. More recent studies were undergoing in adults and showed that poor adherence 
to treatment is a factor that correlates with a lower quality of life. In contrast, educational measures may improve both GSQL and compliance with treatment [31,32]. The same authors showed that educational level, professional activity, or living area does not correlate with GSQL in adults with asthma [32]. This data is similar to our current results.

In conclusion, the general score of quality of life in our study group was lower for children with asthma that belongs to families with lower income. It was not affected by the living area or by the presence of evidence of atopic status.

\section{Consent for Publication}

All co-authors have agreed to the submission and publication of this manuscript. Authors can provide signed consent if required by the Journal Editor.

\section{Acknowledgments}

There were no other contributors to the article than the authors.

\section{Disclosure}

All authors report no conflicts of interest in this work.

\section{References}

1. International Study of Asthma and Allergies in Childhood (ISAAC) Steering Committee (1998) Worldwide variations in the prevalence of asthma symptoms: the International Study of Asthma and Allergies in Childhood (ISAAC). Eur Respir J 12: 315-335.

2. Cherecheş-Panţa P, Popa M, Iacob D, Mureşan M, Dumitraşcu D, et al. (2003) Prevalence of asthma in children aged 7 years from the city of Cluj-Napoca, ISAAC study. Pneumologia 52: 134-140.

3. Gherghe S, Nanulescu MV, Cherecheş-Panţa P, Popa M (2000) Prevalence of asthma in schoolchildren aged 13 to 14 years from the city of Bistrita. Pneumologia 49: 95-99.

4. Cherecheş-Panţa P, Man SC, Deleanu D, Marshall M, et al. (2011) Epidemiological survey six years apart: increased prevalence of asthma and other allergic diseases in schoolchildren aged 13-14 years in ClujNapoca, Romania (based on ISAAC questionnaire). Maedica (Buchar) 6: 10-16.

5. Ellis JR, Nowlis EA (1989) Nursing - A Human Needs Approach. (4 ${ }^{\text {th }}$ edn.), Houghton Mifflin Company, Boston.

6. Rutishauser C, Sawyer S, Bowes G (1998) Quality-of-life assessment in children and adolescents with asthma. Eur Respir J 12: 486-494.

7. Juniper EF, Guyatt GH, Willam A, Griffith LE (1994) Determining a minimal important change in a disease-specific quality of life instrument . J Clin Epidemiol 47: 81-87.

8. Juniper EF, Guyatt GH, Feeny DH, Ferrie PJ, Griffith LE, et al. (1996) Measuring quality of life in children with asthma. Qual Life Res 5: 35-46.

9. Juniper EF (1997) How Important Is Quality of Life in Pediatric Asthma? Pediatr Pulmonol Suppl 15: 17-21

10. Rona RJ (2000) Asthma and poverty. Thorax 55: 239-244.

11. Kumar P, Arora A (1999) Socioeconomic Status and Skin Test Reactivity to Inhaled Allergens in Adults with Asthma and Allergic Rhinitis. ACI International 11: 69-72.

12. Rosinczuk J, Pryzslak M, Uchmanowiz I (2018) Sociodemographic and clinical factors affecting the quality of life of patients with chronic obstructive pulmonary disease. Int J Chron Obstruct Pulmon Dis 13: 2869-2882.
13. Global Initiative for Asthma: Asthma Management and Prevention, 2019.

14. David L, Nanulescu M, Popa M (2001) Quality of life-questionairre validation. Natl Conf Allerg Clin Immunol pp. 26-28.

15. Acheson D (1998) Independent inquiry into inequalities in health. Department of Health, Stationery Office, London.

16. Duran-Tauleria E, Rona RJ (1999) Geographical and socioeconomic variation in the prevalence of asthma symptoms in English and Scottish children. Thorax 54: 476-481.

17. Rona RJ, Hughes JM, Chinn S (1999) Association between asthma and family size between 1977 and 1994. J Epidemiol Community Health 53: 15-19.

18. Garcia DP, Corbett ML, Sublett JL, Pollard SJ, Meiners JF, et al. (1994) Cockroach allergy in Kentucky: a comparison of inner-city, suburban, and rural small town. Ann Allergy 72: 203-208.

19. Ernst P, Demissie K, Joseph L, Locher U, Becklake MR (1995) Socioeconomic status and indicators of asthma in children. Am J Respir Crit Care Med 152: 570-575.

20. Sarpong SB, Hamilton RG, Eggleston PA, Adkinson NF (1996) Socioeconomic status and race as risk factors for cockroach allergen exposure and sensitization in children with asthma. J Allergy Clin Immunol 97: 1397-1401.

21. Chellammal HSJ, Arumugam D, Menon BVV, Menon SMM, Menon M, et al. (2019) Sociodemographic Factors and its Impact on Health-Related Quality of Life (HRQoL) among Adult Asthma Patients in a Private Specialist Hospital in Malaysia. J Young Pharm 11: 404-409.

22. Indolean C, David L, Cherecheş-Panţa P, Nanulescu M (2003) Comparison of subjective and objective methos to asses asthma in chidren. Rev Econom Admin Sanitară, Editura Mediamira, Cluj-Napoca pp. 34-35, 3-4, 92-95.

23. Pop CF, Cherecheş-Panţa P, Nanulescu MV (2005) The evaluation of quality of life in children with asthma. Pneumologia 54: 99-103.

24. Pop CF, Cherecheș-Panța P, Nanulescu M (2006) The quality of life in children with asthma and allergi rhinitis. Pneumologia 55: 74-79.

25. Yann BP, Yunginger JW, Wollan PC, Reed CE, Silverstein MD, et al. (1999) Allergic rhinitis in Rochester, Minnesota residents with asthma: frequency and impact on health care charges. J Allergy Clin Immunol 103: 54-59.

26. Tripathi A, Patterson R (2001) Impact of allergic rhinitis treatment on quality of life. Pharmacoeconomics 19: 891-899.

27. Meltzer EO (1997) The prevalence and medical and economic impact of allergic rhinitis in the United States. J Allergy Clin Immunol 99: 805-828.

28. Yasamin Torfi Y, Bitarafan N, Rajabi M (2015) Impact of socioeconomic and environmental factors on atopic eczema and allergic rhinitis: A cross-sectional study. EXCLI J 14: 1040-1048.

29. Celano M, Geller RJ, Phillips KM, Ziman R (1998) Treatment adherence among low-income children with asthma. J Pediatr Psychol 23: 345-349.

30. Christiansen SC, Martin SB, Schleicher NC, Koziol JA, Mathews KP, et al. (1997) Evaluation of school-based asthma education program for inner-city children. J Allergy Clin Immunol 100: 613-617.

31. Bartosz Uchmanowicz B, Panaszek B, Uchmanowicz I, Rosińczuk J (2016) Clinical factors affecting quality of life of patients with asthma. Patient Preference and Adherence 10: 579-589.

32. Bartosz Uchmanowicz B, Panaszek B, Uchmanowicz I, Rosińczuk J (2016) Sociodemographic factors affecting the quality of life of patients with asthma Patient Preference and Adherence 10: 345-354. 


\section{di \\ нетан}

Advances In Industrial Biotechnology | ISSN: 2639-5665

Advances In Microbiology Research | ISSN: 2689-694X

Archives Of Surgery And Surgical Education | ISSN: 2689-3126

Archives Of Urology

Archives Of Zoological Studies | ISSN: 2640-7779

Current Trends Medical And Biological Engineering

International Journal Of Case Reports And Therapeutic Studies | ISSN: 2689-310X Journal Of Addiction \& Addictive Disorders | ISSN: 2578-7276

Journal Of Agronomy \& Agricultural Science | ISSN: 2689-8292

Journal Of AIDS Clinical Research \& STDs | ISSN: 2572-7370

Journal Of Alcoholism Drug Abuse \& Substance Dependence | ISSN: 2572-9594

Journal Of Allergy Disorders \& Therapy | ISSN: 2470-749X

Journal Of Alternative Complementary \& Integrative Medicine | ISSN: 2470-7562

Journal Of Alzheimers \& Neurodegenerative Diseases | ISSN: 2572-9608

Journal Of Anesthesia \& Clinical Care | ISSN: 2378-8879

Journal Of Angiology \& Vascular Surgery | ISSN: 2572-7397

Journal Of Animal Research \& Veterinary Science | ISSN: 2639-3751

Journal Of Aquaculture \& Fisheries | ISSN: 2576-5523

Journal Of Atmospheric \& Earth Sciences | ISSN: 2689-8780

Journal Of Biotech Research \& Biochemistry

Journal Of Brain \& Neuroscience Research

Journal Of Cancer Biology \& Treatment | ISSN: 2470-7546

Journal Of Cardiology Study \& Research | ISSN: 2640-768X

Journal Of Cell Biology \& Cell Metabolism | ISSN: 2381-1943

Journal Of Clinical Dermatology \& Therapy | ISSN: 2378-8771

Journal Of Clinical Immunology \& Immunotherapy | ISSN: 2378-8844

Journal Of Clinical Studies \& Medical Case Reports | ISSN: 2378-8801

Journal Of Community Medicine \& Public Health Care | ISSN: 2381-1978

Journal Of Cytology \& Tissue Biology | ISSN: 2378-9107

Journal Of Dairy Research \& Technology | ISSN: 2688-9315

Journal Of Dentistry Oral Health \& Cosmesis | ISSN: 2473-6783

Journal Of Diabetes \& Metabolic Disorders | ISSN: 2381-201X

Journal Of Emergency Medicine Trauma \& Surgical Care | ISSN: 2378-8798

Journal Of Environmental Science Current Research | ISSN: 2643-5020

Journal Of Food Science \& Nutrition | ISSN: 2470-1076

Journal Of Forensic Legal \& Investigative Sciences | ISSN: 2473-733X

Journal Of Gastroenterology \& Hepatology Research | ISSN: 2574-2566
Journal Of Genetics \& Genomic Sciences | ISSN: 2574-2485

Journal Of Gerontology \& Geriatric Medicine | ISSN: 2381-8662

Journal Of Hematology Blood Transfusion \& Disorders | ISSN: 2572-2999

Journal Of Hospice \& Palliative Medical Care

Journal Of Human Endocrinology | ISSN: 2572-9640

Journal Of Infectious \& Non Infectious Diseases | ISSN: 2381-8654

Journal Of Internal Medicine \& Primary Healthcare | ISSN: 2574-2493

Journal Of Light \& Laser Current Trends

Journal Of Medicine Study \& Research | ISSN: 2639-5657

Journal Of Modern Chemical Sciences

Journal Of Nanotechnology Nanomedicine \& Nanobiotechnology | ISSN: 2381-2044

Journal Of Neonatology \& Clinical Pediatrics | ISSN: 2378-878X

Journal Of Nephrology \& Renal Therapy | ISSN: 2473-7313

Journal Of Non Invasive Vascular Investigation | ISSN: 2572-7400

Journal Of Nuclear Medicine Radiology \& Radiation Therapy | ISSN: 2572-7419

Journal Of Obesity \& Weight Loss | ISSN: 2473-7372

Journal Of Ophthalmology \& Clinical Research | ISSN: 2378-8887

Journal Of Orthopedic Research \& Physiotherapy | ISSN: 2381-2052

Journal Of Otolaryngology Head \& Neck Surgery | ISSN: 2573-010X

Journal Of Pathology Clinical \& Medical Research

Journal Of Pharmacology Pharmaceutics \& Pharmacovigilance | ISSN: 2639-5649

Journal Of Physical Medicine Rehabilitation \& Disabilities | ISSN: 2381-8670

Journal Of Plant Science Current Research | ISSN: 2639-3743

Journal Of Practical \& Professional Nursing | ISSN: 2639-5681

Journal Of Protein Research \& Bioinformatics

Journal Of Psychiatry Depression \& Anxiety | ISSN: 2573-0150

Journal Of Pulmonary Medicine \& Respiratory Research | ISSN: 2573-0177

Journal Of Reproductive Medicine Gynaecology \& Obstetrics | ISSN: 2574-2574

Journal Of Stem Cells Research Development \& Therapy | ISSN: 2381-2060

Journal Of Surgery Current Trends \& Innovations | ISSN: 2578-7284

Journal Of Toxicology Current Research | ISSN: 2639-3735

Journal Of Translational Science And Research

Journal Of Vaccines Research \& Vaccination | ISSN: 2573-0193

Journal Of Virology \& Antivirals

Sports Medicine And Injury Care Journal | ISSN: 2689-8829

Trends In Anatomy \& Physiology | ISSN: 2640-7752

Submit Your Manuscript: http://www.heraldopenaccess.us/Online-Submission.php 